\title{
A Dynamic Analysis of Rotary Combustion Engine Seals
}

J. Knoll and C. R. Vilmann

Michigan Technological University

Houghton, Michigan

and

H. J. Schock and R. P. Stumpf

Lewis Research Center

Cleveland, Ohio

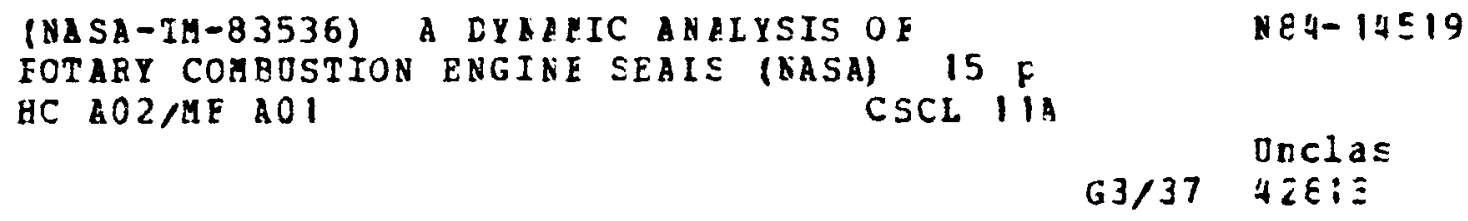

Prepared for the

Annual Congress and Exposition

sponsored by the Society of Automotive Engineers

Detroit, Michigan, February 27-March 2, 1984 
A Dynamic Analysis of Rotary Combustion Engine Seals

J. Knoll and C. R. Vilmann

Michigan Technological University

ME-EM Department

Houghton, Michigan 49931

and

H. J. Schock and R. P. Stumpf

National Aeronautics and Space Administration

Lewis Research Center

cleveland. Ohio 44135 


\section{ORIGINAL PRGE IS OF POOR QUALITY}

\section{ABSTRACi}

Real time work cell pressures are incorporated into a dynamic analysis of the gas sealing grid in Rotary Combustion Engines. The analys is which utilizes only first principal concepts accolunts for apex seal separation from the trochoidal bore, apex seal shifting between the sides of its restraining channel, and apex seal rotation within the restraining channel. The results predict that apex seals do separate from the trochoidal bore and shift between the sides of their channels. The results also show that these two motions are regularly initiated by a sall rotation. The predicted motion of the apex seals compares favorably with experimental results. Frictional losses associated with the sealina grid are also calculated and compare well with measurements obtained in a similar engine. A comparison of frictional losses when using steel ano carbon apex seals has also been made as well as friction losses for single and dual side sealing.

BEFURE STARTING A OISCUSSION of the factors invoived with sealing a Rotary Combustion Engine (RCE) it is helpfui to examine the standard network of seals used in RCEs. Referring to Fig. I which was taken from Ansdale (1)*, one sees the long curved side seals which contact the end covers of the cylinder and three apex seals which separate the three working cellis of the engine. Examination of this sealing network allows appreciation of the additional difficulty involved in sealing RCES. The long length of the side seals and the irregular path traversed by the apex seals present problems different from those encountered in sealing reciprocating piston engines. In this paper, a theoretical dynamic analys is of the forces acting on the seals, is coupled with experimentally obtained cell pres-

Numbers in Darentheses designate references at end of paper.
Sures to obtain a friction model of the gas sealing system. Both the possible separation of the apex seals from the trochoidal bore and the frictional losses associated with this type of sealing configuration will be examined.

Up to the present time, documentation of the forces acting on these seals has not appeared in the literature to any appreciable extent. Jones (2) shows an approximate breakdown of friction losses at $6000 \mathrm{rpm}$ in a Curtiss-Wright RCl-60 engine. Here seal friction losses are reported to be about $11 / 2$ times the losses in the bearings and gears. Yamamoto (3) shows gas sealing losses to be over 50 percent of the total normalized frictional losses in an unspecified rotary engine. To the author's knowledge, no prediction or measurement of the friction associated with each sealing component has been previously published.

Loss of contact between the apex seal ano the trochoidal bore has been discussed by a number of researchers. Eberle and $K$ lomp (4), have cited leakage past the apex seal as a possible cause of higher hydrocarbon emissions and increased specific fuel consumption. Prasse et al. (5) and Rodgers et al. (6), have related seal separation to chatter marks which form on the crochoidal bore creating wear problems. Matsuura et al. (7), experimentally have shown that separation of the apex seal from the bore does take place and have correlated the locations of these separations with low, non-negative, contact forces. Both Prasse and Matsuura use Ansdale's typical cell pressure profile and inertial force relationship. Since a component of the contact force acting between an apex sea? and the trochoidal bore arises from the pressure differential across the apex seal, an important aodition to the past analyses is the inclusion of the actual differential pressure data obtained under operating conditions.

\section{EXPERIMENTAL PRESSURE MEASUREMENT}

The experimental measurement system used to obtain cell pressures during both motoring and 
firing conditions was developed by NASA. Since this system has been discussed in detail in a previous paper by Schock et al. (8), only a brief description will be presented here. Four piezoelectric pressure transducers were mounted in a turbocharged 1978 Mazda 12A nonemission type (no catalytic converter) engine. The locations of these transducers are shown in Fig. 2. Four transoucers were used in order that a continuous pressure versus crank angle plot from a single system of interest could be recorded. Whenever the rotor occupied a position where two transducers were active, the average difference between the two transducers was calculated and used to offset the trailing transducer's output. A signal correlator was also designed to reduce the data resulting from these four transducers to that of the pressure acting in one cell during a complete cycle. Pressures were sampled at 2048 equally spaced angular positions throughout the $1080^{\circ}$ of mainshaft rotation.

Pressure versus crank angle plots for all the operating conditions examined have a shape similar to that shown in Fig. 3. These plots depict the pressure acting in one working cell throughout $1080^{\circ}$ of crank angle rotation. The $0^{*}$ crank angle reference for these plots correspond to the location where the system of interest unjer consideration contains a minimum volume and intake begins. The significant differences between the traces taken at the various operating conditions tested are the magnitude peak pressure near top-deadcenter (TDC) and the value of the intake basel ine pressure. Values for the intake manifold pressure ranged from $37 \mathrm{kPa}$ at $2939 \mathrm{rpm}$ under motoring conditions to $351.6 \mathrm{kPa}$ at 6000 $r$ m while turbocharged firing. The compressionfiring peak pressures ranged from $682.6 \mathrm{kPa}$ at $2939 \mathrm{rpm}$ motoring to $3061.4 \mathrm{kPa}$ at $6000 \mathrm{rpm}$ firing. A summary of the data collected and the conditions under which that data was collected is shown in Table 1.

\section{APEX SEAL LIFT OFF}

An examination of the apex sealing configuration revealed that there are three possible movements of the apex seal with respect to its channel which could initiate separation. The seal could: (1) slide away from the bore while retaining contact with one of the channel's sides; (2) the seal could shift between the leading and trailing edges of its channel; and (3) the seal could pivot about one of its lower edges. In the case of the sliding movement separation would automatically occur. The other two initiating movements could cause redistribution of the forces acting on the seal resulting in the seal beginning to slide away from the bore.

In order to examine the possibility of these three movements and separation, Newton's second law was employed. The forces acting on an apex seal are shown in $F i g .4$. The value of $F_{5}$ was chosen by measuring the apex seal deflection at 25 characteristic locations within the rotor housing and then measuring the amount of force required to deflect the seal spring for the given deflections. Fs was determined to be $5.510 \mathrm{ff}$ and nearly constant over the entire operating range. This nearly constant force is accounted for by the small amount of radial seal movement over the cycle and the value of the apex seal spring constant. The force $\left(F_{N}\right)$ used against the side seal was 5.010 f.

Additional forces arising from rotor motion due to changes in bearing clearance or thermal distortion of the rotor housing are bevond the scope of this work and have not been included. In the analysis, the problem has been assumed to be two-dimensional with the forces $F_{C}, F_{N}$, and $F_{S}$ being resultant quantities. Their frictional counterparts ${ }^{\mu} \mathrm{F}_{\mathrm{C}}$ and ${ }_{\mu N} \mathrm{~F}_{N}$ were determined utlizing the assumption of coulomb friction. The pressures $P_{a}$ and $P_{b}$, are those acting in the leading and trailing cells respectively. The values of $P_{a}$ and $P_{b}$ are input to the analys is from the experimental data. They are assumed to be uniform throughout the working cell including the regions next to the seal. Summation of the forces in the and $n$ directions yieids:

$$
\begin{aligned}
& F_{E}=F_{N}+F_{C} \sin -{ }^{{ }_{C}} F_{C} \cos \\
& +P_{a} w[A \cos B-A \cos -h] \\
& +P_{b} W[A \cos -A \cos B] \\
& F_{\eta}=F_{S}-F_{C} \cos --{ }^{{ }_{C}} F_{C} \sin +{ }{ }_{N} F_{N} \\
& +P_{a} w\left[\frac{B}{2}-A \sin \varphi\right]+P_{b} w\left[A \sin -\frac{B}{2}\right]
\end{aligned}
$$

where here $2 B$ is the angle subtended by the cylinorical seal head and is equal to $\sin ^{-1}$ $(B / 2 A), w$ is the width of the rotor, while. is the angle of seal obliquity and is given in Ansdale ds:

$$
=\cos ^{-1}\left[\frac{R+3 e \cos 2 a}{\left(9 e^{2}+R^{2}+6 e R \cos 2 a\right)}\right]
$$

In the above equation $R$ and $e$ define a epitrochoidal cylinder with $2(R+e)$ as the major diameter and $2(R-e)$ the minor diameter. A rotary engine's (Wankel) above has a trochoida) shape. A trochoid may be generated from an epitrochoid by maintenance of a constant perpendicular distance between the two. In the case of a rotary engine this distance corresponds to the seal head radius $A$. The major diameter of a wankel engine is the term $2(R+e+A)$ and the minor dianeter $2(R-e+A)$. In Eqs. (I) and (2), seal contact between the seal and its retaining groove was assumed to be perfect. This assumption disallows gas penetration into the contact region and assumes zero pressure acting on the contacted portion of the seal. 


\section{ORYGANAL FAGE IS \\ OF POOR QUALITY}

The $c$ and $n$ coordinates were assumed to be always parallel and perpendicular to the seal's sides, respectively.

The acceleration of the seal's cg, which was assumed to lie at one haif the seal's height, was determined by direct differentiation of the equathons describing the epitrochoidal path which th: $\mathrm{cg}$ follows. These equations are derived from the equation describing the trochoidal bore:

$$
\begin{aligned}
& x=e \cos (3 a)+\left(R-\frac{n}{2}-A \cos B\right) \cos a \\
& y=e \sin (3 a)+\left(R-\frac{n}{2}-A \cos \theta\right) \sin a
\end{aligned}
$$

Gifferentiation of these equations twice results in:

$$
\begin{aligned}
& a_{x}=-\omega^{2}\left[9 e \cos ^{3} a+\left(R-\frac{h}{2}+A \cos \theta\right) \cos a\right] \\
& a_{y}=-\omega^{2}\left[9 e \sin ^{3} a+\left(R-\frac{h}{2}+A \cos \theta\right) \sin a\right]
\end{aligned}
$$

which represents the acceleration of the seals $\mathrm{cg}$ when the engine runs at a constant speed $w$. These accelerations are related to the fixed $x-y$ coordinate frame shown in Fig. 4. In applying the linear form of Newton's second law, it was convenient to use the $c$ and $n$ directions. Thus these acceleration components were transformed using:

$$
\begin{aligned}
& a_{c}=a_{x} \cos a+a_{y} \sin \alpha \\
& a_{n}=-a_{x} \sin a+a_{y} \cos \alpha
\end{aligned}
$$

If we denote the resultant of the pressure loading on the seal as $P_{t}$ and $P_{n}$ defined as:

$P_{c}=P_{a} w[A \cos B-A \cos \varphi-h]$

$$
\begin{array}{r}
+P_{b} w[A \cos -A \cos B] \\
P_{n}=\left(P_{a}-P_{b}\right) w\left(\frac{B}{2}-A \sin \varphi\right)
\end{array}
$$

then Newton's laws yield:

$$
\begin{aligned}
& F_{C}=\frac{m\left(\mu_{N} a_{c}-a_{n}\right)+p_{n}-u_{N} p_{c}+F_{S}}{\left(\mu_{N}+u_{C}\right) \sin +\left(1-u_{N} \mu_{C}\right) \cos } \\
& F_{N}=m a a_{E}-P_{E}+F_{C}\left(\mu_{C} \cos \bullet-\sin \bullet\right)
\end{aligned}
$$

where $m$ is the mass of the seal. In that portion of the cycle where the seal is in contact with the bore, $F$ positive, there is no -elative motion between the seal and the grove in the $n$ direction and $M N$ is equal to zero. Setting ${ }_{N} N$ equal to zero while the seal is in contact with the bore neglects sticktion which allows for a fricticnal force on the seals side with a magnitude lower than ${ }_{\mu N} F_{N}$. In a dynamic situation when small vibrations are present it was felt that this sticktion force would quickly relax allowing the seal to assume a minimum energy state. The angular form of Newton's second law was also employed to find the location of $F_{N}$ :

$$
\begin{aligned}
& \bar{x}=\left(\frac{1}{F_{N}}\right)\left[F_{C} \sin -\mu_{C} F_{C} \cos \varphi\right. \\
& +P_{D} A m(B-) \sin \left(\frac{B+e}{2}\right) \\
& \left.-P_{a} A w(B+\theta) \sin \left(\frac{B-a}{2}\right)\right]\left(A \cos B-\frac{h}{2}\right) \\
& +{ }^{\mu}{ } F c^{A}
\end{aligned}
$$

With the forces and locations of the resultants acting on the seal known, the three types of movement were examined. Hith the seal ini.ially in contact with the bore, the vilues of $F_{C}, F_{N}$, and $x$ were calculated at the successive sampling points of the pressure data. Whenever $F_{N}$ changes sign or $x$ obtained a value less than $-h / 2$ the seal had shifted to the opposite side of its groove. For the locations where the seal was in contact with the leading edge of the groove, the force equations were adjusted to show the changed pressure distribution. Separation initiated whenever $F_{C}$ attained a negative value. From that point in the cycle until the location where the seal recontacted the bore, $F_{C}$ was set to zero in EQ. (11) and a was calculated. Integration of the time dependent $a_{n}$ allowed the amount of seal separation to be traced. Since pressure data was available only at distinct points, this integration was carried out numerically. The direction of the frictional force was adjusted through the numerical integration such that motion of the seal relative to its channel was always retarded. For the operating conditions studied the maximum contact force was nominally 440 Newtons $\left(1001 b_{f}\right)$ and occurred when the apex seal was located from $540^{\circ}$ to $620^{\circ}$ ATDC.

For each of the engine conditions described in Table 1, seal separation was examined. The seal dimensions corresponding to the engine tested were input into the previous equations and are listed in the appendix. For this discussion the $0^{\circ}$ rotor reference position corresponds to the minimum chamber volume for a system of interest on the intake stroke. The angular position depicts the motion of the trailing apex seal. Flgure 5 shows a $0^{\circ}$ crank angle position of the apex seal under discussion and the position of this seal at various crank angle locations. From 
analys is of the motoring data, it was found that lateral movement of the apex seal from the leading to the trailing side of its channel occurred at approximately the same location for all runs. This switch occurred close to $\mathbf{4 6 5}$ mainshaft degrees or at a position slightly after the major axis of the engine as the seal approaches the ignition side. In this position, the cell trailing the seal is in the intake portion of its cycle, while the leading cell is undergoing compression. The analys is predicted no lift off from the bore at this location. Also in the motoring mode, the returning shift from the trailing to the leading wall was predicted to occur in the region of 844 to 891 mainshaft degrees. This shift was acconpanied by seal lift off in four of the six motoring conditions tested and occurred between the minor and major axis of the bore on the ignition side.

From analysis of the firing data, which was only taken at the 100 percent throttle position. it was learned that seal transfer from the leading to the trailing side of the channel occurred in the range of $528^{\circ}$ to $545^{\circ}$ of crank angle. his shift also occurred after the major axis of the housing, as the seal moved toward the ignition side. No seal separation from the bore accompanied this transfer. The predicted shift from the trailing to the leading side occurred in the range of $896^{\circ}$ to $920^{\circ}$ of crank angle. This location occurred later in the cycle as engine speed increased. Separation from the bore was predicted to be present at the lowest speed tested and disappeared as engine speed increased. A tabulation of these resilts is shown in Table 2 .

A comparison was made between the experimentally orawn conclusions of Matsuura $(7,10)$ and the results presented here. Matsuura reports a transfer from the trailing toward the leading side of the channel after the minor axis of the engine on the ignition side. He also reports the return shift to occur between the minor and major axis, with this movement occurring later with increased engine speed. These observations were confirmed with the exception of change in location of the leading to the trailing shift with engine speed. Matsuura also reports that the seal may lose contact for as much as $30^{\circ}$ of crank angle. When the seal dimensions used by Matsuura were utilized along with data which produced a long separation 12053 rom at 66 percent throttle $7.26^{\circ}$ of lift off was predicted. One of Matsuura's conclusions which was difficult to confirm, was his observation of increased gap with increased engine speed after $2000 \mathrm{rpm}$. This analysis shows the opposite to be true. At high engine speeds, Juring firing conditions, no separation occurs.

\section{FRICTIONAL LOSSES ASSOCIATED WITH SEALING}

A dynamic analys is of the forces involved with the spex seal and a knowledge of the cell pressures, allows the calculation of the frictional losses associated with the sealing grid.
In this development the assumption of Coulomb friction will again be made and any end effects due to the complicated junction of the side and apex seals will be ignored. The basic definition of work

$$
w=\int F d r
$$

will be employed in the consideration of both apex and side seals.

In the case of apex seals $F$ in the preceding equation becomes the frictional component of the contact force, $\mu^{F} C_{C}$, and or becomes a differential displacement along the trochoidal bore when frictional losses are calculated. The trochoidal bore is defined by adding a perpendicular displacement of magnitude $A$ to the expressions defining an epitrochoid, given in Eqs. (5i and $(6)$ :

$$
\begin{aligned}
& x=e \cos ^{3} a+R \cos a+A \cos (a+-) \\
& x=e \sin ^{3} a+R \sin a+A \sin (a+\bullet)
\end{aligned}
$$

The displacement or may be defined in terms of the angular displacement da utilizing

$$
d r^{2}=d x^{2}+d y^{2}
$$

and differentiating Eqs. (14) and (15). With the aid of Eqs. (14) to (16), the integral defining of the work done by an apex seal (eq. (13)) may now be evaluated as an integrat:- over the angle a. Since $F_{C}$ is known at the cu48 points where the cell pressures have been sampled, this integration was performed numerically for each of the operating conditions shown in Table 1 . The numerical integration was carried out utillzing a sixth order Simpson's rule.

Frictional work associated with the side seals was computed in a similiar way. Two sidesealing configurations were examined. The first model used consists of 12 side seal segments per rotor. Outer side seals, those closest to the rotor face, were assumed to be pushed against the end housing by the combined action of a spring and the gas pressure from their cells. The inner side seals were assumed to be kept in contact with the end housings by the action of a spring alone. The second side sealing system was similar to the first except the frictional contribution of the inner seal was neglected. Since the frictional work done at the side seais varies with location on the seal, this work must be calculated by evaluation of the double integral:

$$
W=\iint d F_{5 s} d r
$$

Here $d F_{s s}$ is a frictional force acting on an incremental length dl of the seal, and $d r$ is the distance through which this frictional force moves. 


\section{ORIGINAL PAGE IS \\ OF POOR QUALITY}

Aricsale (1), gives a circular arc approximation of the rotor face relative to the center of the mainshaft. The same equations were used to approyimate the form of the side seals with a decreased radius input to account for the distance between the rotor face and seal location. These equations are given by:

$$
\begin{aligned}
& x=e \cos 3 a+(g+e) \cos \left(a-\frac{2 \pi}{3}\right) \\
&-(g-e+R) \cos \left(r+\frac{2 \pi}{3}-a\right) \\
& y=e \sin 3 a+(g+e) \sin \left(a-\frac{2 \pi}{3}\right) \\
&+(g-e+R) \sin \left(r+\frac{2 \pi}{3}-a\right)
\end{aligned}
$$

where

$$
\begin{aligned}
g=e R\left[1+\cos \left(\frac{\pi}{3}\right)\right] R & {\left[1+\cos \left(\frac{\pi}{3}\right)\right]-2 e } \\
& -27.07^{\circ}<r<27.07^{\circ}
\end{aligned}
$$

Here the limits on $r$ were calculated from geometrical considerations. Differentiation of Eqs. (19) and (20) and use of the relationship given by Eq. (16), allows the double integral to be evaluated numerically. Simpson's $1 / 3$ rule was used for evaluation of this double integral.

once the work ilitegrals, Eqs. (13) and (18) have been evaluated, the frictional work associated with sealing is known for one rotor revolution. It is then necessary only to multiply by engine speed to determine the frictional power consumed by the sealing grid. This frictional loss is not the same as the mechanical frictional loss (FMEP), associated with engine operation since it neglects such components as oil seal friction, gearing friction and the friction associated with the bearings. However, measurements of the various frictional losses by CurtissWright (9), show that seal friction is the biggest single frictional loss, 50 percent higher than in the bearings and gears.

Having determined the gas sealing grids frictional horsepower (GSHP), the gas sealing mean effective pressure (GSMEP) can be calculated by:

$$
\text { GSMEP }=\frac{(\text { GSHP })(33000)(12)}{V_{d}(\mathrm{rpm})}
$$

with $v_{d}$ being the volume displaced by the engine and rpm the engine speed. Figures 6 and 7 show the value of GSMEP as a function of throttle position for the motored speeds of 2053 and 2939 rpm. The ordinates in these figures have normalized, with respect to the frictional coefficients
Detween the seals and their respective running surfaces. The GSMEP for the apex and side seals are plotted as a function of mainshaft speed for the firing engine in Fig. 8. Table 3 lists combined values of GSMEP, assuming a coefficient of friction of 0.05 between the apex seal and bore and a coefficient of friction of 0.10 between the side seals and end housings. These values of were obtained from Matsuura (7).

Because of mechanical problems associated with measuring torque during motoring in our test apparatus, motoring mean effective pressure. (MMEP) was not measured during this series of tests. In previous work Schock et al. $(8)$, reports values of FMEP of $70 \mathrm{kPa}$ and $105 \mathrm{kPa}$ while motoring at $2000 \mathrm{rpm}$ and $2900 \mathrm{rpm}$, respectively. Pumping losses were subtracted from MAEP in $h$ is measurements. Schock's experiment was conducted in a rotary engine of similar geometry to the present engine except that it was fitted with steel seals.

The present analysis predicts GSMEP of 62.7 $\mathrm{kPa}$ and $63.4 \mathrm{kPa}$ for $2053 \mathrm{rpm}$ and $2925 \mathrm{rpm}$, respectively. A lis gram seal mass was used to approximate the mass of the steel seals. The pressure inputs to the model were those recorded while motoring the engine with the carbon apex seals. The similar values of the GSMEP predicted, is accounted for by the fact that pressure dominates the GSMEP calculation and the pressure traces during motoring for the two cases of interest were nearly identical. As can be seen in Figs. 6 and 7, GSMEP is only modestly affected by seal mass. It has been stated by other researchers that the gas sealing components may account for over 50 percent of the total frictional losses (2,3, and 9). Using this assumption and considering the fact that the coefficient of friction is not well known, these results would appear to be in good agreement.

\section{CONCLUSIONS}

The primary conclusion to be drawn from this work concerns the importance of having accurate values of the cell pressures $P_{a}$ and $P_{0}$ near the seal tip. Previous analytical studies have not had cell data of this type and were unable to predict the seal separation which was experimentally known. It has been demonstrated that a dynamic analys is can yield reasonable results, when average cell pressures are input for the pressures acting near the seal. If the pressures acting in the vicinity of the seals were known, even more accurate predictions of separation could be made. This analys is has also shown that a rotation may initiate seal transfer between the side of the apex seal channel. Without considering a rotation to initiate movement, it was found that under most operating conditions tested, seal transfer from side to side was not predicted. Further, these calculations show the friction losses due to the side seals are on the same order of magnitude and possioly larger than apex seal frictional losses. Finally, it has been shown that a dynamic analysis of the sealing system can result in reasonable predictions of the 
frictional losses associated with the gas sealing systen.

\section{REFERENCES}

1. R. F. Ansoale, "The Wankel RC Engine." South Brunswick, N. J.: A. S. Barnes, 1969.

2. C. Jones, "The Curtiss-Wright Rotating Combustion Engines Today:" SAE Transactions. Vol. $73,1965,00.127-147$.

3. K. Yamamoto, "Rotary Engine." Hiroshima, Japan: Toyo Kogyo, 1981.

4. M. K. Eberle and E. O. Klomp. "An Evaluation of the Potential Performance Gain from Leakage Reouction in Rotary Engines," SAE Paper No. 730117 , presented at the International Automotive Engineering Congress, Detroit, Michigan, January 1973.

5. H. F. Prasse, H. E. McCormick, and R. D. Anderson. "A Critical Analysis of the Rotary Engine Sealing Problem," SAE Paper Ho. 730118, presented at the Mational Automobile Engineering Heeting, Detroit, Michigan, May 1972 .
6. T. W. Rodgers, W. Lenke, J. Leferre, and T. Okzawa, "Lubricant Studies in Rotary Combustion Engines," SAE Paper Mo. 720467, presented at the National Automobile Engineering Meeting, Detroit, Micnigan, May 1972.

7. K. Matsuura, $k$. Terasak $i$, and 1 . Wat anabe, "The Behavior of a Rotary Engine Apex Seal Against the Trochoidal Surface." Bulletin of the JSME, Vol. 21. November 1978, pp. $1642-1651$.

8. H. J. Schock, W. J. Rice, and P. R. Meng, "Experimental Analysis of IMEP in a Rotary Conbustion Engine - Inoicated Mean Effective Pressure," SAE Paper No. 810150, presented at the International Congress and Exposition, Cobo Hall, Detroit, Michigan, February 2981.

9. J. P. Morbye, "The Wankel Engine Design Development Applications." Philadelphia: Cnilton Book Co., 1971.

10. K. Matsuura, K. Terasaki, and I. Watanabe, "The Relative Behavior of Rotary Engine Apex Seal to the Walls of a Slot." Bullet in of the JSME, Vol. 19, Noventer 1976, PD. 1367-1375. 
TABLE 1. - CELL PRESSURES AND OPERATING CONDITIONS TESTED

\begin{tabular}{|c|l|c|c|c|}
\hline $\begin{array}{l}\text { Engine } \\
\text { speed }\end{array}$ & $\begin{array}{l}\text { Operating } \\
\text { condition }\end{array}$ & $\begin{array}{c}\text { Throttle } \\
\text { position, } \\
\text { percent }\end{array}$ & $\begin{array}{c}\text { Maximum cell } \\
\text { pressure, } \\
\text { kPa }\end{array}$ & $\begin{array}{c}\text { Minimum cell } \\
\text { pressure, } \\
\text { kPa }\end{array}$ \\
\hline 2053 & Motoring & 9 & 786 & 48 \\
2053 & Motoring & 33 & 1510 & 86 \\
2053 & Motoring & 67 & 1655 & 84 \\
2053 & Motoring & 100 & 1675 & 89 \\
2939 & Motoring & 10 & 683 & 37 \\
2939 & Motoring & 30 & 1338 & 72 \\
2939 & Motoring & 60 & 1662 & 81 \\
2939 & Motoring & 100 & 1682 & 80 \\
4000 & Firing & 100 & 2593 & 253 \\
5000 & Firing & 100 & 2937 & 325 \\
6000 & Firing & 100 & 3061 & 352 \\
7000 & Firing & 100 & 2910 & 325 \\
\hline
\end{tabular}

TABLE 2. - APEX SEAL MOVEMENT

\begin{tabular}{|c|c|c|c|c|c|c|}
\hline \multirow[t]{2}{*}{ rpm } & \multirow[t]{2}{*}{$\begin{array}{l}\text { Throttle, } \\
\text { percent }\end{array}$} & \multirow{2}{*}{$\begin{array}{l}\text { Leading to } \\
\text { trailing } \\
\text { shift, } \\
\text { deg }\end{array}$} & \multirow[t]{2}{*}{$\begin{array}{l}\text { Separation; } \\
\text { distance }\end{array}$} & \multirow{2}{*}{$\begin{array}{l}\text { Trailing to } \\
\text { leading } \\
\text { shift, } \\
\text { deg }\end{array}$} & \multicolumn{2}{|c|}{$\begin{array}{l}\text { Separation; } \\
\text { distance }\end{array}$} \\
\hline & & & & & deg & $\mathrm{mm}$ \\
\hline $2053 M^{*}$ & 9 & 468 & None & 872 & $871-874$ & 0.0013 \\
\hline $2053 M^{\star}$ & 33 & 464 & None & 851 & $844-854$ & .0559 \\
\hline $2053 M^{*}$ & 67 & 459 & None & 845 & $839-848$ & .0381 \\
\hline $2053 M *$ & 100 & 460 & None & 847 & $839-850$ & .0584 \\
\hline $2939 M^{*}$ & 10 & 459 & None & 891 & None & Norie \\
\hline $2939 M *$ & 30 & 471 & None & 854 & None & None \\
\hline $2939 M^{*}$ & 60 & 468 & None & 845 & $843-848$ & .0305 \\
\hline $2939 M *$ & 100 & 468 & None & 844 & $842-845$ & .0008 \\
\hline $4000 \mathrm{~F}^{\star \star}$ & 100 & 532 & None & 896 & $890-897$ & .0003 \\
\hline $5000 \mathrm{~F} \star \star$ & 100 & 540 & None & 909 & None & None \\
\hline $6000 \mathrm{~F} \star \star$ & 100 & 545 & None & 914 & None & None \\
\hline 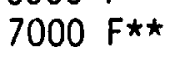 & 100 & 528 & None & 920 & None & None \\
\hline
\end{tabular}

$\star M$ - Motoring condition.

$\star \star F$ - Firing condition. 
TABLE 3. - GAS SEALING MEAN EFFECTIVE PRESSURE (GSMEP)

\begin{tabular}{|c|c|c|c|}
\hline rpm & $\begin{array}{c}\text { Throttle, } \\
\text { percent }\end{array}$ & $\begin{array}{c}\text { (2 side seals) } \\
\text { GSMEP, } \\
\text { KPa }\end{array}$ & $\begin{array}{c}\text { (1 side seal) } \\
\text { GSMEP, } \\
\text { kPa }\end{array}$ \\
\hline 2053 Motoring & 9 & 52.0 & 39.9 \\
2053 Motoring & 33 & 70.9 & 58.8 \\
2053 Motoring & 67 & 73.7 & 61.6 \\
2053 Motoring & 100 & 74.3 & 62.2 \\
2939 Motoring & 10 & 50.5 & 38.4 \\
2939 Motoring & 30 & 65.9 & 53.8 \\
2939 Motoring & 60 & 74.0 & 61.9 \\
2939 Motoring & 100 & 74.4 & 63.3 \\
4000 Firing & 100 & 109.7 & 97.6 \\
5000 Firing & 100 & 129.3 & 117.2 \\
6000 Firing & 100 & 130.2 & 126.1 \\
7000 Firing & 100 & 138.4 & 126.3 \\
\hline
\end{tabular}

$\star_{\mu}=0.1$ side seals.

$\star_{\mu}=0.05$ apex seal. 


\section{ORIGNAL PAGE is \\ OF POOR QUALITY}

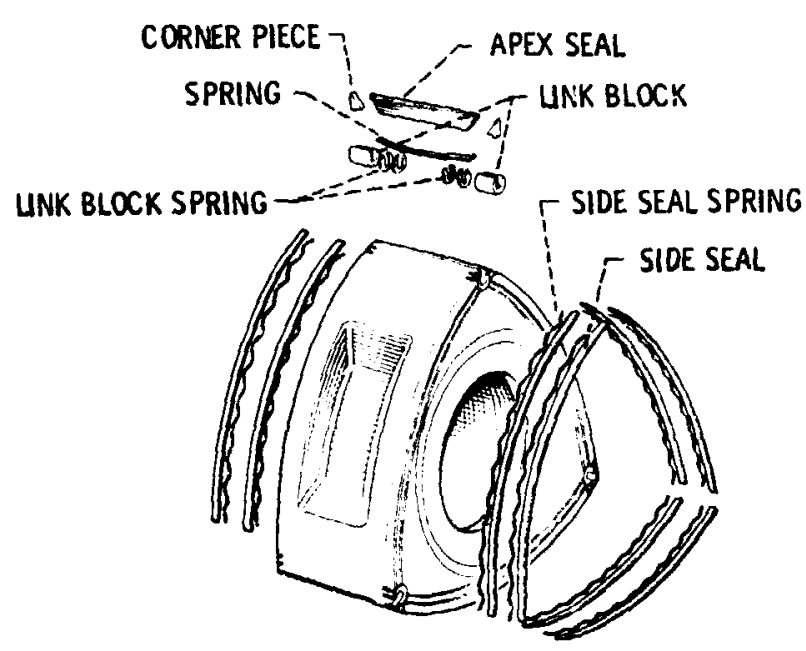

Figure L. - Typical sealing grid for a rotary combustion engine.

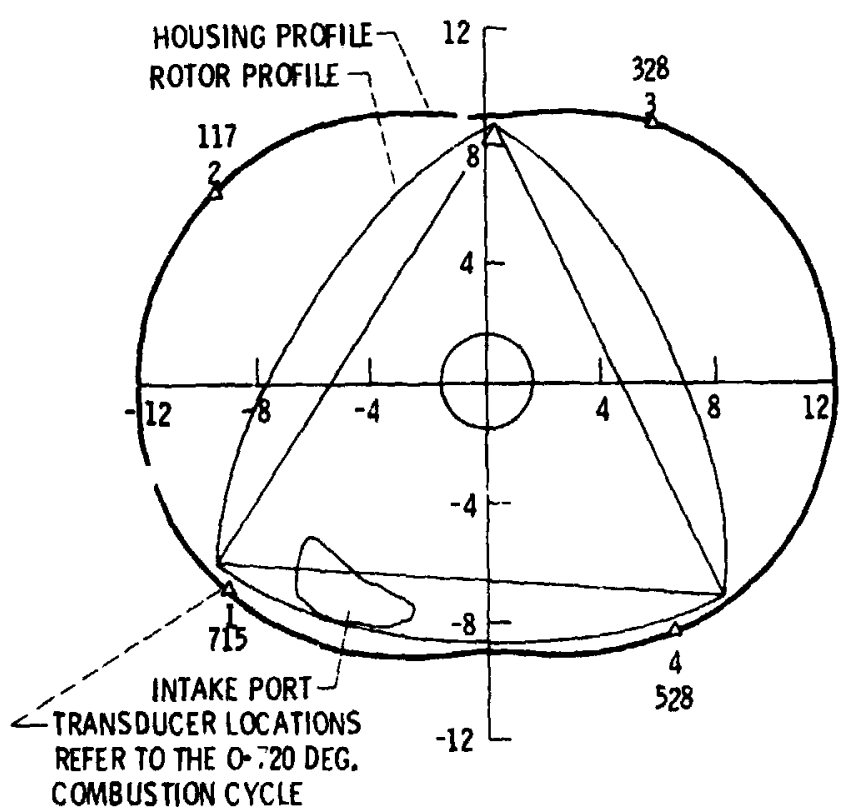

Figure 2. - Transducer locations. 
OROMU:L PROE IS

OF POCR OHLLITY

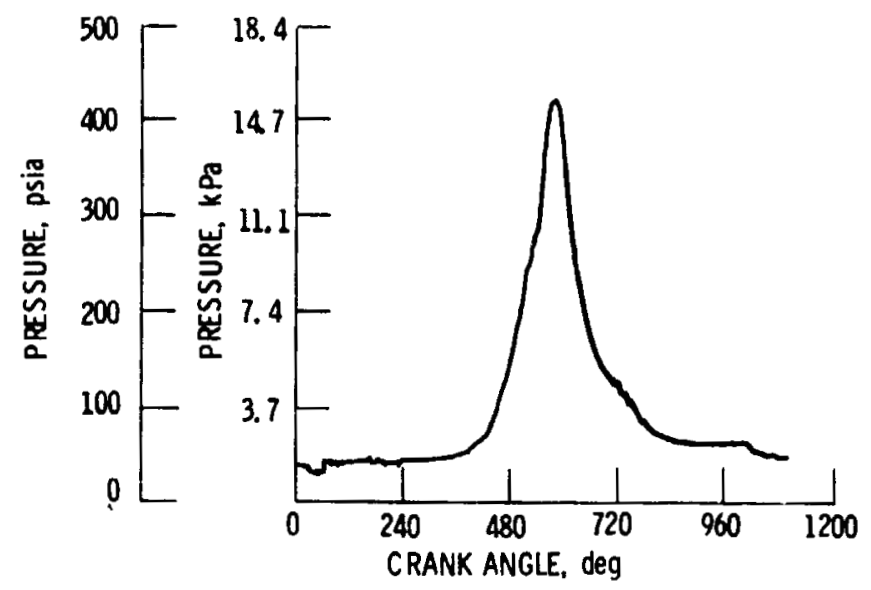

Figure 3. - Typical working cell pressure trace.

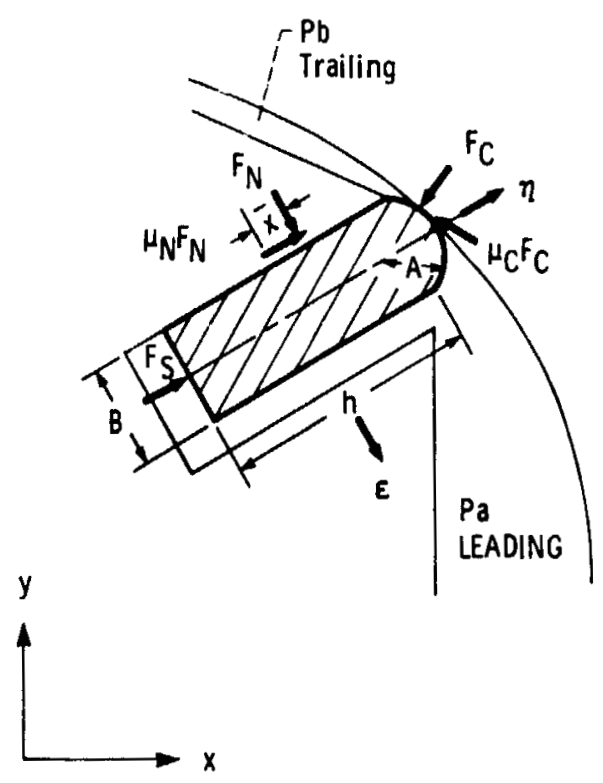

Figure 4. - forces acting on an apex seal. 


\section{ORTONAL PAQE IS \\ OF POOR OIIALITY}

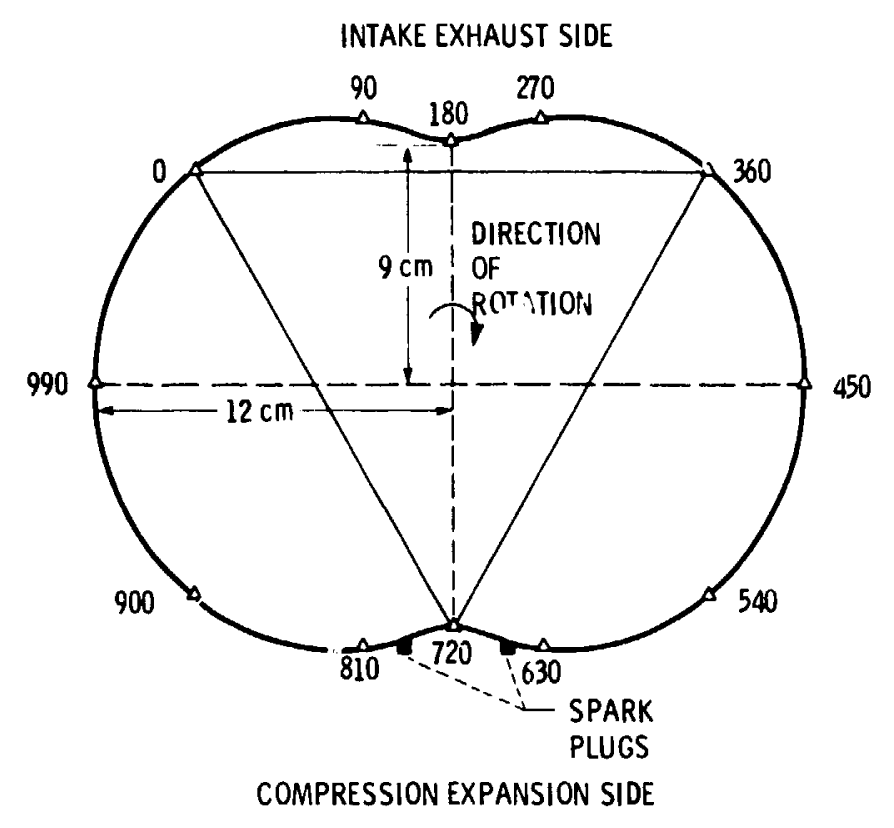

Figure 5. - Trochoidal characteristic dimensions and 'sbeling.

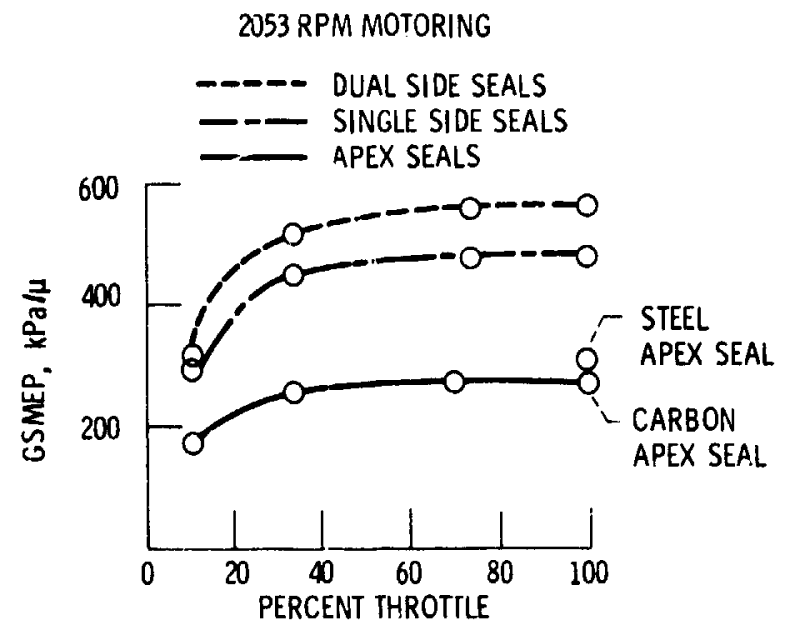

Figure 6. - GSMEP for $2053 \mathrm{rpm}$ motoring. 
ORIGTNAL PAES IS
OF POOR QUALITY

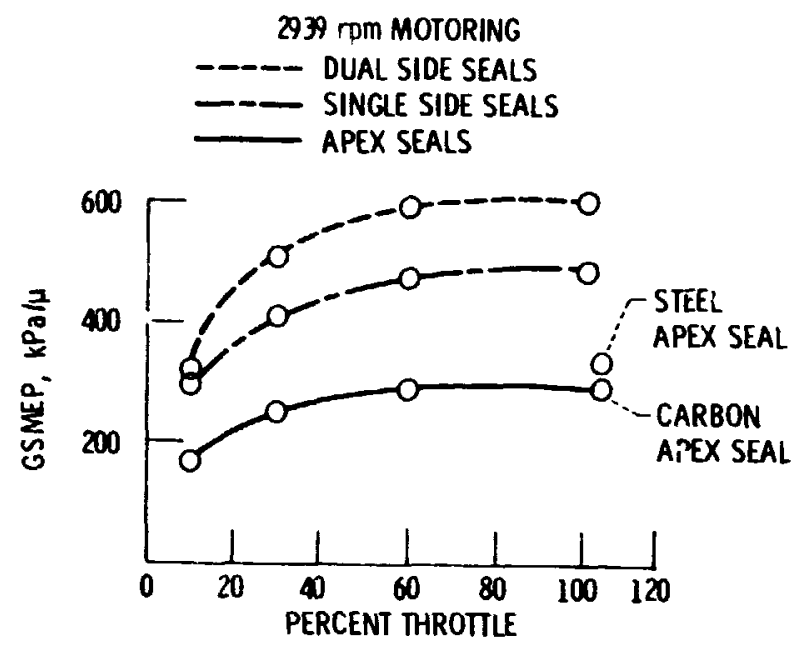

Figure 7. - GSMEP for $2939 \mathrm{rpm}$ motoring

FIRING 100 PERCENT THROTTLE

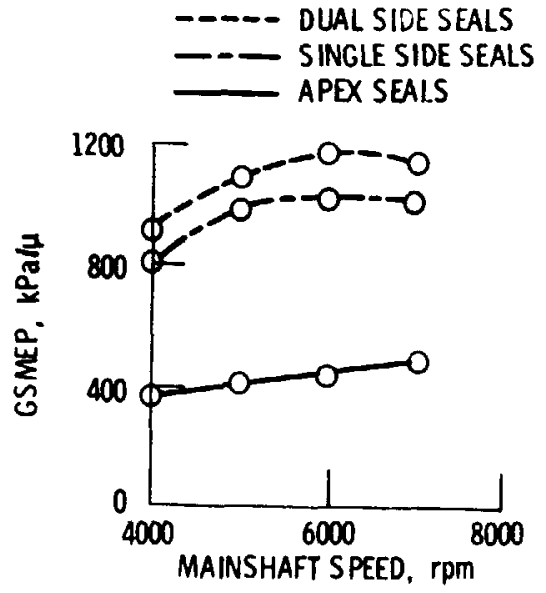

Figure 8. - GSMEP for Firing at 100 percent Throttle. 


\section{CPICXIS! PXEE IS}

OF POCÁ QUALITY

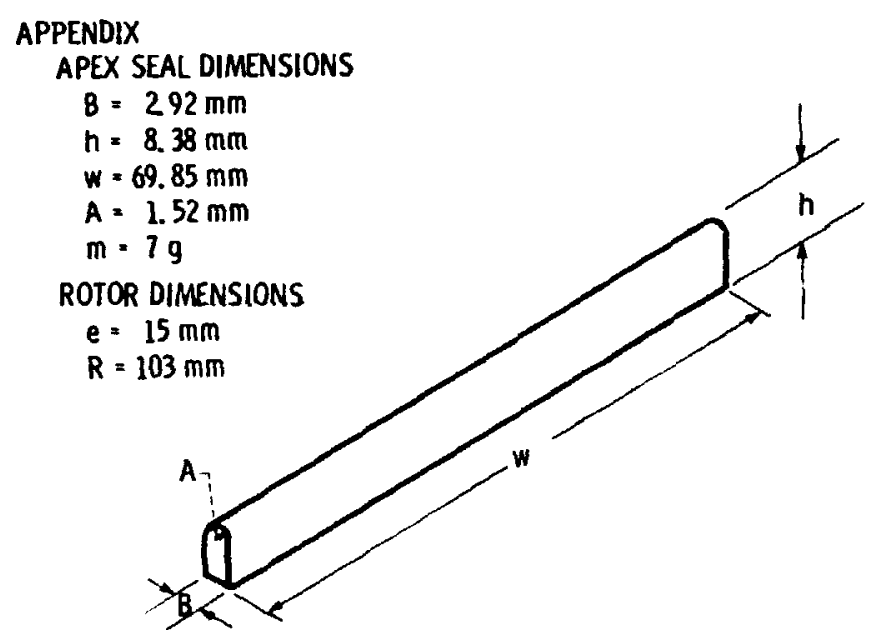

Figure 9. - Apex seal characteristic dimensions. 